\title{
Pengaruh Model Pembelajaran Predict-Observe-Explain Terhadap Kemampuan Berpikir Kreatif Siswa Pada Mata Pelajaran IPA
}

\author{
Ani Rosidah ${ }^{1}$, Yeni Dwi Kurino ${ }^{2}$ \\ PGSD, FKIP, Universitas Majalengka \\ Email: anirosidah.cjr@gmail.com
}

\begin{abstract}
Abstrak
Tujuan penelitian ini yaitu untuk mengetahui keefektifan model pembelajaran POE terhadap kemampuan berpikir kreatif siswa antara pembelajaran yang menggunakan model POE dengan pembelajaran yang menggunakan model konvensional dalam pembelajaran IPA materi Cahaya dan Sifat-sifatnya. Desain penelitian ini menggunakan Quasi Experimental Design dengan bentuk Nonequivalent Control Group Design. Populasi dalam penelitian ini yaitu siswa kelas V-A dan V-B SD Negeri Cijati yang berjumlah 54 siswa.Teknik sampling yang digunakan dalam penelitian ini yaitu probability sampling dengan metode simple random sampling. Berdasarkan hasil uji hipotesis data kemampuan berpikir kreatif siswa dengan perhitungan menggunakan uji hipotesis komparatif dua sampelin dependen diperoleh nilai signifikansi pada kolom Equalvariances assumed sig. (2tailed)sebesar 0,014. Nilai signifikansi tersebut kurang dari 0,05 $(0,014<0,05)$, sehingga Ha diterima dan Ho ditolak, atau kemampuan berpikir kreatif siswa dengan penerapan model POE lebih tinggi dari pada kemampuan berpikir kreatif siswa dengan penerapan model pembelajaran konvensional. Jadi dapat disimpulkan bahwa, penerapan model POE terbukti efektif terhadap kemampuan berpikir kreatif siswa pada pembelajaran IPA materi cahaya dan sifat-sifatnya.
\end{abstract}

Kata Kunci: Model POE, Kemampuan Berpikir Kreatif, IPA

\begin{abstract}
The purpose of this study is to determine the effectiveness of the POE learning model on students' creative thinking skills between learning using the POE model and learning using conventional models in science learning the material of Light and its Properties. The design of this study used a Quasi Experimental Design in the form of the Nonequivalent Control Group Design. The population in this study were students of class V-A and V-B SD Negeri Cijati totaling 54 students. The sampling technique used in this study was probability sampling with a simple random sampling method. Based on the results of the hypothesis test of students' creative thinking ability data by calculating using a comparative hypothesis test of two dependent samples, a significance value was obtained in the Equalvariances column assumed sig. (2-tailed) of 0.014 . The significance value is less than 0.05 $(0.014<0.05)$, so Ha is accepted and Ho is rejected, or the creative thinking ability of students with the application of the POE model is higher than the creative thinking ability of students with the application of conventional learning models. So it can be concluded that the application of the POE model has proven to be effective on students' creative thinking skills in science learning about light material and its properties
\end{abstract}

Keywords: POE Model, Creative Thinking Ability, Science,

\section{PENDAHULUAN}

Ilmu Pengetahuan Alam (IPA)

merupakan ilmu yang mempelajari usaha manusia dalam memahami alam semesta dan segala isinya melalui metode ilmiah yakni observasi dan eksperimentasi, yang nantinya 
diharapkan menghasilkan kesimpulan yang tepat dan akurat. Melalui observasi dan eksperimen siswa tidak hanya akan belajar tentang fakta dan konsep tetapi juga akan belajar cara berpikir dan pemecahan masalah yang dapat diaplikasikan dalam kehidupan sehari-hari.

Seiring dengan tingkat kompleksitas dalam segala aspek kehidupan modern yang sangat tinggi pada era globalisasi, kemampuan berpikir kritis, kreatif, dan produktif di kalangan peserta didik sangat mutlak diperlukan. Hal ini sejalan dengan tujuan pembelajaran IPA yang memberikan kesempatan kepada semua peserta didik mulai dari sekolah dasar untuk membekali peserta didik kemampuan berpikir logis, analitis, sistematis, kritis dan kreatif, dan kemampuan bekerja sama. Kemampuan berpikir kreatif dapat dikembangkan melalui aktivitasaktivitas kreatif dalam IPA.

Berpikir kreatif diartikan sebagai suatu kegiatan mental yang digunakan seseorang untuk membangun idea tau gagasan baru (Ruggiero dan Evans dalam Siswono, 2007). Membangun ide-ide berarti memunculkan ide-ide yang berkaitan dengan masalah yang diberikan baik yang bersumber dari pembelajaran di dalam kelas maupun berasal dari pengalaman sehari-hari.

Namun pada kenyataannya, pelaksanaan proses pembelajaran Ilmu Pengetahuan Alam (IPA) yang diterapkan di sekolah dasar masih lemah. Proses pembelajaran yang terjadi selama ini kurang mampu mengembangkan kemampuan berpikir kreatif siswa. Pelaksanaan proses pembelajaran yang berlangsung di kelas hanya diarahkan untuk menghafal informasi yang disampaikan oleh guru. Kegiatan pembelajaran IPA yang terpusat pada penyampaian materi cenderung akan mendorong siswa untuk menghafal informasi yang diterima. Selain itu, selama ini proses pembelajaran IPA di sekolah dasar masih banyak yang dilaksanakan secara konvensional. Pembelajaran yang bersifat konvensional lebih berpusat pada guru JURNAL PENDIDIKAN DAN KONSELING VOLUME 3 NOMOR 2 TAHUN 2021 (teacher centered) dan kurang mengaktifkan siswa.

Penerapan model konvensional dalam suatu kelas akan menjadikan kelas pasif dan kegiatan pembelajaran menjadi tidak bermakna. Hal tersebut terjadi karena siswa tidak diberikan kesempatan untuk mengungkapkan ide ataupun mengaplikasikannya dalam bentuk demonstrasi. Minimnya kesempatan siswa dalam menuangkan gagasan akan sangat menghambat proses berpikir kreatif siswa dalam konsep IPA pada diri siswa itu sendiri.

Hal yang sama terjadi di kelas V SDN Cijati , terutama pada pembelajaran IPA. Berdasarkan wawancara dengan guru kelas $\mathrm{V}$ SDN Cijati, peneliti memperoleh data nilai IPA pada tahun lalu. Dari data tersebut, dapat diketahui bahwa siswa belum mampu menyerap dan memahami materi secara maksimal. Hal ini dikarenakan siswa tidak berpartisipasi secara aktif dalam kegiatan pembelajaran. Siswa merasa bosan dengan pembelajaran yang berlangsung. Pada akhirnya hal ini berdampak pada hasil belajar siswa yang tidak maksimal.

Joyce (1992) dalam Trianto (2009: 22) mengemukakan bahwa "setiap model pembelajaran mengarahkan kita ke dalam mendesain pembelajaran untuk membantu peserta didik sedemikian rupa sehingga tujuan pembelajaran tercapai”. Model pembelajaran yang digunakan dalam kegiatan pembelajaran bukan hanya disesuaikan dengan tujuan yang hendak dicapai tetapi disesuaikan pula dengan bahan atau materi pembelajaran serta karakteristik dan kebutuhan siswa. Model pembelajaran IPA yang digunakan di sekolah dasar dilakukan dengan penelitian sederhana yang memungkinkan siswa memperoleh pengalaman langsung melalui pengamatan, diskusi, dan penyelidikan sederhana sehingga dapat menumbuhkan sikap ilmiah siswa yang dapat melatih sikap berpikir kreatif melalui pembelajaran IPA.

Model pembelajaran POE (PredictObserve-Explain) merupakan suatu model 
yang efisien untuk menciptakan diskusi para siswa mengenai konsep ilmu pengetahuan sehingga dapat meningkatkan kemampuan berpikir kreatif siswa. Model pembelajaran POE melibatkan siswa dalam meramalkan suatu fenomena, melakukan observasi melalui demonstrasi atau eksperimen, dan akhirnya menjelaskan hasil demonstrasi dan ramalan mereka sebelumnya (Indrawati dan Setiawan 2009: 45). Model pembelajaran POE bertujuan untuk mengajarkan siswa untuk belajar mandiri dalam hal memecahkan suatu permasalahan. Keunggulan dari model pembelajaran POE ini adalah keaktifan siswa dalam penggalian informasi, dan pola interaksi yang baik antar siswa maupun dengan guru dalam proses pembelajaran.

Berdasarkan uraian diatas, fokus penelitian ini adalah apakah terdapat perbedaan kemampuan berpikir kreatif yang signifikan antara kelas yang menggunakan model pembelajaran POE dengan kelas yang tidak menggunakan model pembelajaran $\mathrm{POE}$ dalam pembelajaran IPA di Sekolah Dasar?

\section{METODOLOGI PENELITIAN}

Metode penelitian yang digunakan dalam penelitian ini yaitu Quasi Eksperimental Design. Menurut Sugiyono (2014: 77) bentuk desain eksperimen ini mempunyai kelompok kontrol tetapi tidak dapat berfungsi sepenuhnya untuk mengontrol variabel-variabel luar yang mempengaruhi pelaksanaan eksperimen. Pada penelitian Quasi Eksperimen, kelompok eksperimen dan kontrol tidak dipilih secara random melainkan menggunakan kelompok yang sudah ada. Kelompok dalam suatu kelas biasanya sudah seimbang, sehingga apabila peneliti membentuk kelompok baru akan menyebabkan keseimbangan kelas menjadi terganggu. Populasi dalam penelitian ini adalah siswa kelas V-A dan V-B SDN Cijati.

Penelitian yang dilaksanakan merupakan penelitian eksperimen untuk menguji apakah model pembelajaran POE dapat berpengaruh terhadap kemampuan berpikir kreatif siswa (variabel terikat). Data yang digunakan dalam penelitian ini merupakan data kuantitatif. berupa nilai hasil pengamatan kemampuan berpikir kreatif siswa pada saat proses pembelajaran IPA dengan menggunakan model POE. Deskripsi data dalam penelitian ini meliputi jumlah siswa, skor rata-rata, median, skor minimal, skor maksimal, rentang, varians, dan standar deviasi kemampuan berpikir kreatif siswa.

Teknik sampling yang digunakan dalam penelitian ini yaitu simple random sampling. Simple random sampling adalah teknik pengambilan anggota sampel dari populasi yang dilakukan secara acak tanpa memperhatikan strata yang ada dalam populasi itu. (Sugiyono 2014: 82). Penentuan sampel dilakukan dengan teknik simple random sampling karena untuk menghindari kesalahan sampling yang disebabkan adanya pemeriksaan yang tidak lengkap tentang populasi dan penelitian yang hanya dilakukan berdasarkan sampel. Menurut Riduwan (2010: 20), salah satu cara untuk mengontrol kesalahan sampling yaitu dengan jalan mengambil sampel berdasarkan sampel acak. Teknik pengumpulan data yang meliputi teknik dokumentasi, observasi dan tes.

\section{HASIL PENELITIAN DAN PEMBAHASAN}

Berdasarkan hasil penelitian diperoleh rata-rata skor pretes dengan output SPSS dapat diketahui bahwa nilai signifikansi untuk kelas eksperimen sebesar 0,200 ; sedangkan pada kelas kontrol nilai signifikansinya sebesar 0,200. Data dinyatakan berditribusi normal jika nilai signifikansi lebih dari 0,05 . Dengan demikian, dari output normalitas data awal sebelum dilakukan penelitian, sampel kedua kelas dinyatakan berdistribusi normal karena nilai signifikansi keduanya telah lebih dari 0,05 .

Berdasarkan ouput uji homogenitas independent sample $t$ test nilai pretest IPA, terlihat nilai signifikansi pada kolom Levene Test for Equality of Variences sebesar 0,869. 
Signifikansi 0,185 telah lebih dari 0,05 sebagai syarat data dikatakan homogen. Berdasarkan uji homogenitas data nilai pretest kemampuan berpikir kreatif siswa baik kelas eksperimen maupun kelas kontrol dapat disimpulkan bahwa Ho diterima, atau nilai pretest kemampuan berpikir kreatif siswa homogen.

Normalitas Data Nilai Postest Kemampuan Berpikir Kreatif Siswa nilai signifikansi kelas eksperimen sebesar 0,192 sedangkan nilai signifikansi kelas kontrol sebesar 0,152. Nilai signifikansi hasil belajar

Tabel 1.1. Uji Kesamaan Rata-rata Posttest Kemampuan Berpikir Kreatif Siswa kelas eksperimen lebih besar dari 0,05 $(0,192>0,05)$ dan kelas kontrol lebih besar dari $0,05(0,152>0,05)$. Dari data tersebut maka kedua kelas tersebut dinyatakan berdistribusi normal karena nilai signifikansi keduanya lebih dari 0,05 .

Nilai signifikansi pada kolom sig. sebesar 0,356. Nilai signifikansi tersebut lebih dari 0,05. Dari data tersebut maka data nilai posttest kemampuan berpikir kreatif siswa pada kelas eksperimen dan kontrol tersebut dinyatakan homogen.

Independent Samples Test

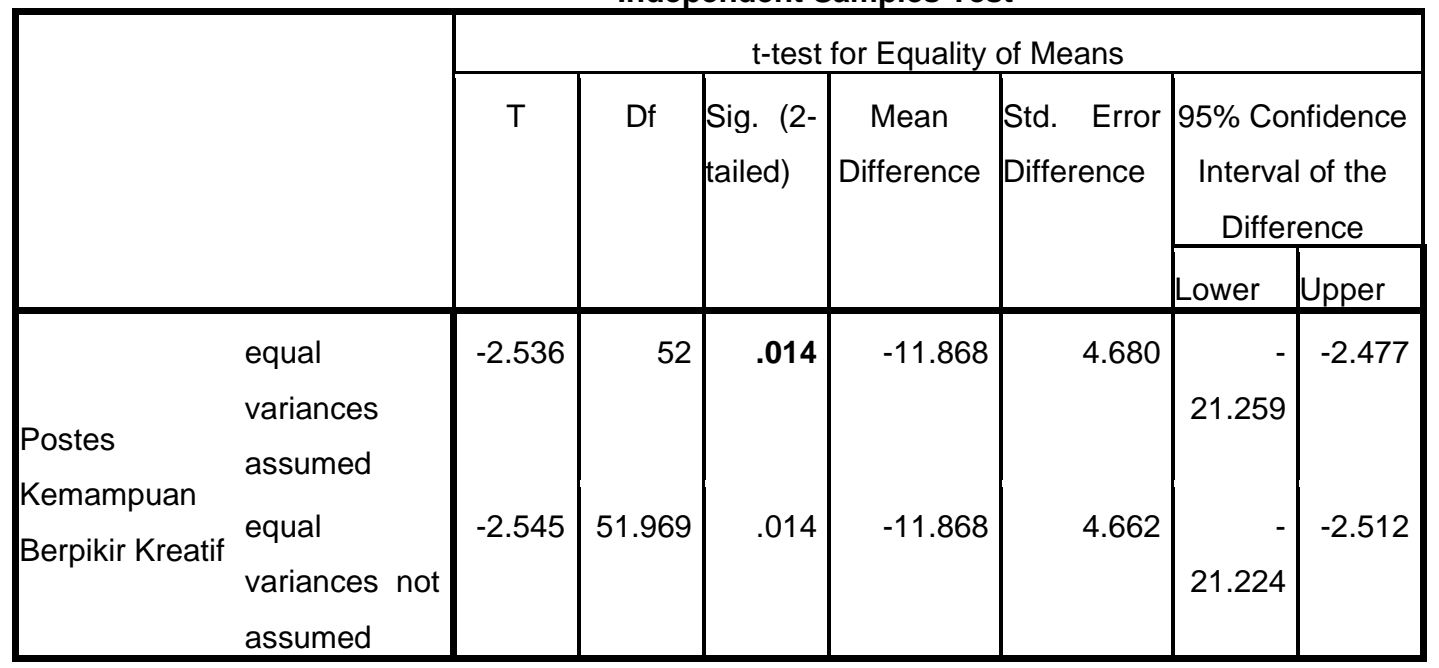

Berdasarkan tabel 1.1 diatas bahwa nilai signifikansi pada kolom Equal variances assumed sig. (2-tailed) sebesar 0,014. Nilai signifikansi tersebut kurang dari $0,05(0,014<$ 0,05). maka dapat disimpulkan bahwa Ho ditolak dan $\mathrm{Ha}$ diterima atau terdapat perbedaan kemampuan berpikir kreatif antara siswa kelas $\mathrm{V}$ yang mendapat pembelajaran dengan model POE dengan kelas yang mendapat pembelajaran dengan model konvensional.

Pengambilan data penelitian dilakukan dengan melaksanakan serangkaian proses pembelajaran baik di kelas eksperimen maupun kontrol. Data yang dibutuhkan oleh peneliti meliputi data kemampuan berpikir kreatif siswa setelah diberikan perlakuan, yaitu pembelajaran di kelas eksperimen yang menggunakan model POE serta pembelajaran di kelas kontrol yang menggunakan model konvensional.

Pembelajara IPA pada kelas eksperimen yaitu Perlakuan diberikan pada siswa kelas V-B SDN Cijati sebagai kelas eksperimen. Pembelajaran dilaksanakan dengan menggunakan model POE. Pada kegiatan inti, guru terlebih dahulu melakukan pengenalan materi dikaitkan dengan peristiwa nyata dalam kehidupan sehari-hari. Kegiatan guru pada awal pembelajaran bertujuan untuk mendorong pola pikir siswa yang relevan dengan kehidupan sehari-hari sehingga siswa 
mudah memahami materi yang diberikan. Selanjutnya, pada tahap elaborasi guru mendorong siswa untuk terlibat aktif dalam proses pemerolehan materi pembelajaran.

$$
\text { Model POE adalah model }
$$

pembelajaran yang memuat tiga tahapan yaitu prediksi, observasi dan eksplanasi. Siswa melakukan prediksi dengan menganalisis jawaban pertanyaan yang terangkum dalam LKS I. Pertanyaan tersebut terkait dengan materi berupa peristiwa yang sering ditemui siswa dalam kesehariannya. Siswa terlihat sangat antusias menganalisis jawaban pertanyaan dengan sesekali bertanya kepada guru apabila ada pertanyaan yang kurang dimengerti. Setelah memprediksi, siswa diarahkan untuk membuktikan jawaban prediksi dengan melakukan kegiatan percobaan berdasarkan petunjuk percobaan yang tertera dalam LKS II. Siswa mengamati hasil percobaan dan kemudian menganalisis serta mendiskusikannya bersama dengan anggota kelompok. Pada kegiatan percobaan, setiap siswa terlibat aktif didalamnya dan terlihat ketertarikan siswa untuk melaksanakan langkah-langkah percobaan. Beberapa siswa yang pada kegiatan sebelumnya terlihat kurang antusias, mulai terdorong untuk terlibat aktif dalam mengikuti pembelajaran. Setiap kelompok berdiskusi dengan anggota kelompok, serta menganalisis hasil pengamatan berdasarkan percobaan yang telah dilakukan. Kegiatan selanjutnya yaitu siswa bertugas mempresentasikan hasil kerja di hadapan teman-temannya untuk melaporkan hasil temuannya yang sekaligus mencocokkan hasil percobaan/pengamatan dengan prediksi sebelumnya. Siswa mampu menjelaskan hasil pengamatan/percobaan dengan baik tanpa ditunjuk oleh guru. Selain itu, tahap ini melatih keberanian siswa untuk mengemukakan pendapat atau gagasan di hadapan teman-temannya.

Pada kelas eksperimen diperoleh nilai rata-rata skor pretes yaitu 40,35 dan rata-rata skor postes yaitu 73,65 sehingga rata rata skor poretes dan postes terdapat kenaikan sebesar
33,30. Ini berarti rata-rata kemampuan berpikir kreatif siswa setelah diberikan perlakuan lebih baik dari rata-rata kemampuan berpikir kreatif siswa sebelum diberikan perlakuan.

Pembelajaran IPA pada kelas kontrol yaitu pada siswa kelas V-A SDN Cijati menggunakan model konvensional. Pada kegiatan awal, guru menyampaikan materi secara urut. Setelah itu guru memberikan contoh soal. Selanjutnya guru meminta siswa mengerjakan soal latihan. Pada saat mengerjakan soal, guru memantau setiap kerja siswa dan membimbing siswa yang mengalami kesulitan. Sebelum akhir pembelajaran guru memberi kesempatan kepada siswa untuk bertanya mengenai halhal yang belum dipahami dari materi yang sudah diajarkan.

Pada pembelajaran konvensional pembelajaran masih terpaku pada penyampaian materi dari guru kepada siswa karena memang didominasi oleh pemberian ceramah oleh guru. Guru masih mendominasi proses pembelajaran sehingga siswa cenderung pasif karena keterlibatan yang terbatas. Ini terbukti dari nilai rata-rata skor postes di kelas eksperimen lebih baik dari nilai rata-rata skor postes di kelas kontrol yaitu sebesar 61,79. Hal tersebut dikarenakan pada kelas eksperimen yang menggunakan model pembelajaran POE siswanya lebih aktif.

Pengaruh model pembelajaran POE terhadap kemampuan berpikir kreatif siswa, Rata-rata hasil belajar yang diperoleh siswa melalui nilai posttest pada akhir pembelajaran, menunjukkan hasil yang memuaskan setelah siswa melaksanakan pembelajaran dengan menggunakan model POE. Hal tersebut ditandai dengan nilai ratarata postes eksperimen lebih baik dari nilai rata-rata postes di kelas kontrol.

Uji hipotesis hasil dengan perhitungan menggunakan rumus independent sample $t$ test melalui program SPSS versi 21 menunjukkan bahwa nilai signifikansi yang 
diperoleh $0,014<0,05$ maka dapat disimpulkan bahwa Ho ditolak dan $\mathrm{Ha}$ diterima atau terdapat perbedaan kemampuan berpikir kreatif IPA antara siswa kelas V yang mendapat pembelajaran dengan model POE dengan kelas yang mendapat pembelajaran dengan model konvensional.

Hasil penelitian menunjukkan bahwa model POE terbukti efektif terhadap kemampuan berpikir kreatif siswa. Dari awal hingga akhir pembelajaran, langkah/tahapan yang disajikan model POE telah didesain untuk mengarahkan siswa untuk menggali pengetahuan yang dimiliki sebelumnya. Pengetahuan tersebut dapat berasal dari materi yang telah diperoleh sebelumnya atau bahkan dari pengalaman dalam kehidupan sehari-hari. Pengetahuan awal yang dimiliki menjadi modal bagi siswa untuk memahami dan menguasai konsep materi yang disampaikan guru dalam pembelajaran selanjutnya. Guru berperan sebagai fasilitator dan motivator untuk membimbing dan mengarahkan siswa agar proses pembelajaran berjalan dengan baik sesuai tahapan POE. Siswa mengkonstruksi pengetahuan yang telah dimiliki dengan menghubungkannya dengan materi pembelajaran. Siswa berlatih dan mengasah keterampilannya dalam berpikir serta menganalisis peristiwa yang terjadi hingga memperoleh konsep materi yang diajarkan. Dengan mengalami, mengamati, mengkonstruksi, menganalisis, dan menyimpulkan sendiri konsep materi yang diberikan, siswa belajar dari peristiwa yang secara nyata dialami sehingga mereka mampu memperoleh pengetahuan yang bermakna.

\section{SIMPULAN}

Berdasarkan hasil analisis data yang telah diperoleh dari hasil pretes dan postes pada pembelajaran IPA materi cahaya dan sifat-sifatnya dengan menggunakan model pembelajaran POE di kelas V SDN Cijati, diperoleh kesimpulan bahwa terdapat peningkatan kemampuan berpikir kreatif siswa dengan menggunakan model pembelajaran POE di lihat dari hasil nilai ratarata postes siswa lebih besar dari nilai ratarata pretes siswa dengan selisih nilai sebesar 33,30, berdasarkan hasil analisis data perbedaan rata-rata dua sampel, diperoleh nilai rata-rata postes kelas eksperimen lebih besar dari nilai rata-rata postes kelas kontrol sehingga terdapat pengaruh model pembelajaran POE terhadap kemampuan berpikir kreatif siswa pada mata pelajaran IPA.

\section{DAFTAR PUSTAKA}

Aly, A. dan E. Rahma. (2011). Ilmu Alamiah Dasar. Jakarta: PT Bumi Aksara

Arikunto, S. (2010). Dasar-Dasar Evaluasi Pendidikan. Jakarta: PT Bumi Aksara

Hergenhahn, dan M. H. Olson. (2008). Theories of Learning (Teori Belajar). Terjemahan Tri Wibowo B.S. Jakarta: Kencana

Idrus, M. (2009). Metode Penelitian Ilmu Sosial Pendekatan Kuantitatif dan Kualitatif. Yogyakarta: Erlangga

Indrawati, dan W. Setiawan. (2009). Pembelajaran Aktif, Kreatif, Efektif, dan Menyenangkan untuk Guru SD. Bandung: PPPPTK IPA

Jihad, A dan Haris, A. (2008). Evaluasi Pembelajaran. Yogyakarta: Multi Pressindo

Priyatno, D. (2010). Paham Analisa Statistik Data dengan SPSS. Yogyakarta: MediaKom

Riduwan. (2012). Pengantar Statistika Sosial. Bandung: Alfabeta

Rusman. (2012). Model-model Pembelajaran: Mengembangkan Profesionalisme Guru. Jakarta: PT Raja Grafindo Persada

Saefudin, A. A. (2011). Proses Berpikir Kreatif Siswa Sekolah Dasar 
Berkemampuan Matematika Tinggi Dalam Pemecahan Masalah Matematika Terbuka. Universitas PGRI Yogyakarta

Sari, K. N. (2014). Keefektifan Model Pembelajaran POE Terhadap Aktifitas Dan Hasil Belajar IPA Materi Perubahan Sifat Benda Pada Siswa Kelas V Sdn Kejambon 4 Kota Tegal. Universitas Negeri Semarang

Semiawan, C. R. (2008). Belajar dan Pembelajaran Prasekolah dan Sekolah Dasar. Jakarta: PT Indeks

Sudarma, M. (2013). Mengembangkan Keterampilan Berpikir Kreatif. Jakarta: PT Rajagrafindo Persada

Sudjana, N. (2012). Penilaian Hasil Proses Belajar Mengajar. Bandung: PT Remaja Rosdakarya

Sugiyono. (2014). Metode Penelitian Kuantitatif Kualitatif dan $R \& D$. Bandung: Alfabeta

Susanto, A. (2013). Teori Belajar dan Pembelajaran di Sekolah Dasar. Jakarta: Kencana

Suyono, dan Hariyanto. (2012). Belajar dan Pembelajaran Teori dan Konsep Dasar. Bandung: PT Remaja Rosdakarya

Trianto. (2009). Mendesain Model Pembelajaran Inovatif-Progresif: Konsep, Landasan, dan Implementasinya pada Kurikulum Tingkat Satuan Pendidikan (KTSP). Jakarta: Kencana

Undang-Undang Republik Indonesia Nomor 20 tahun 2003 tentang Sisdiknas. (2006). Bandung: Citra Umbara.

Warsono, dan Hariyanto. (2012). Pembelajaran Aktif. Bandung: PT Remaja Rosdakarya

Widyaningrum, R. (2013). Pengembangan Modul Berorientasi POE (Predict, JURNAL PENDIDIKAN DAN KONSELING VOLUME 3 NOMOR 2 TAHUN 2021
Observe, Explain) Berwawasan Lingkungan pada materi Pencemaran untuk Meningkatkan Hasil Belajar Siswa. Jurnal Bioedukasi Universitas Sebelas Maret Vol 6: 100-117 